\title{
ANALISIS KEPUASAN PELAYANAN PASIEN PADA INSTALASI RAWAT JALAN DI RUMAH SAKIT RUMAH SAKIT UMUM DAERAH EMBUNG FATIMAH BATAM DENGAN PENDEKATAN LEAN SERVICE DAN SERVICE PERFOMANCE
}

\author{
Adhitomo Wirawan ${ }^{1}$ ), Venia Yunita ${ }^{2}$ ) \\ 1)Prodi Administrasi Bisnis Terapan, Politeknik Negeri Batam, email: adhitomo@polibatam.ac.id \\ 2)Prodi Administrasi Bisnis Terapan, Politeknik Negeri Batam, email: veniaYunita30@ gmail.com
}

\begin{abstract}
The aim of this research is useful to know the satisfaction of outpatient at Rumah Sakit Embung Fatimah Batam. Service satisfaction is the end result perceived by the user of the product or service, whether it is less, equal or exceeds the desired expectations. By using lean searvice pedekantan and service performance. This study resulted in five indicators of service quality at Rumah Sakit Embung Fatimah Batam which is included in quadrant I group which is the main priority to be improved to exceed patient expectation. The five indicators are: adequate waiting room facilities (2.5), waiting room environment and good lighting (77,50), accessible information access (2,9), service to patient complaints done quickly and responsive $(2,9)$, the officer receives advice from the patient (2.9).
\end{abstract}

Keywords : Service Satisfaction, Lean Searvice, and Service Performance

\begin{abstract}
Abstrak
Penelitian ini bertujuan untuk mengetahui kepuasan pelayanan pasien rawat jalan di Rumah Sakit Umum Daerah Embung Fatimah Batam. Kepuasan pelayanan merupakan hasil akhir yang dirasakan oleh pengguna produk atau jasa, baik itu kurang, sama atau melebihi harapan yang dinginkan. Dengan menggunakan pedekantan lean searvice dan service performance. Penelitian ini menghasilkan lima indikator kepuasan pelayanan pada Rumah Sakit Umum Daerah Embung Fatimah yang termasuk dalam kelompok kuadran I yaitu prioritas utama untuk di perbaiki guna melebihi harapan dari pasien. Kelima indikator tersebut adalah: ketersediaan fasilitas ruang tunggu yang memadai $(2,5)$, lingkungan ruang tunggu dan penerangan baik $(77,50)$, ketersediaan sarana informasi yang mudah dijangkau $(2,9)$, pelayanan terhadap keluhan pasien dilakukan dengan cepat dan tanggap $(2,9)$, petugas menerima saran dari pasien $(2,9)$.
\end{abstract}

Kata kunci: Kepuasan Pelayanan, Lean Searvice, dan Service Performance 


\section{PENDAHULUAN}

Rumah sakit terutama rumah sakit milik pemerintah daerah merupakan salah satu institusi pelayanan publik dibidang kesehatan. Rumah sakit menurut Peraturan Menteri Kesehatan Republik Indonesia Nomor 340/MENKES/PER/III/2010 adalah institusi pelayanan kesehatan yang menyelenggarakan pelayanan kesehatan perorangan secara paripurna yang menyediakan pelayanan rawat inap, rawat jalan, dan gawat darurat. Tugas dan fungsi rumah sakit adalah melaksanakan upaya pelayanan kesehatan secara berdaya guna dan berhasil dengan mengutamakan penyembuhan dan pemulihan yang dilaksanakan secara serasi dan terpadu dengan peningkatan dan pencegahan serta pelaksanaan upaya rujukan.

Salah satu rumah sakit di Kota Batam adalah Rumah Sakit Embung Fatimah. RSUD EF adalah rumah sakit umum milik pemerintah yang beralamatkan di Jalan Letjen Soeprapto Blok D 1-9, Batu Aji, Bukit Tempayan, Batu Aji, Kota Batam, Kepulauan Riau. Awal berdirinya RSUD EF pada tahun 1986 yang merupakan Puskesmas Rawat Jalan Batu Aji. RSUD EF merupakan rumah sakit tipe $B$ yang berdasarkan Menteri Kesehatan Indonesia Nomor HK.02.03/I/0154/2013.

Sebagai rumah sakit milik pemerintah dengan sarana poliklinik yang lengkap bukanlah faktor yang menetukan kualitas rumah sakit tersebut yang paling utama adalah kualitas pelayanan yang ditunjukan setiap insan rumah sakit melalui kinerja yang baik yang diberikan kepada pasien mulai dari pendaftaran hingga keluar dari rumah sakit. Kualitas pelayanan rumah sakit terhadap para konsumennya merupakan suatu hal yang sangat penting yang pada akhirnya akan mampu memberikan kepuasan kepada konsumennya. Sehingga diharapkan fungsi dan tujuan rumah sakit tersebut dapat tercapai dalam Chitami (2013).

Pada Rumah Sakit Embung Fatimah masih banyak yang mengeluhkan tentang pelayanan yang diberikan pada proses pelayanan rawat jalan. Oleh karena itu peneliti mengambil proses pelayanan pada rawat jalan sebagai objek penelitian. Diharapkan penelitian ini dapat memberikan usulan perbaikan kualitas pelayanan pada proses pelayanan rawat jalan agar memaksimalkan kepuasan pelayanan yang didapat oleh pasien yang berunjung.

\section{RUMUSAN MASALAH}

Berdasarkan latar belakang penelitian yang telah dijelaskan diatas maka, dirumuskan masaalah sebagai berikut :

1. Bagaimana tingkat kualitas pelayanan pada instalasi rawat jalan Rumah Sakit Embung Fatimah berda sarkan kepuasan pasien menggunakan service performance

2. Apakah indikator pelayanan yang berpengaruh terhadap ketidakpuasan kualitas pelayanan pada instalasi rawat jalan pada Rumah Sakit Embung Fatimah

3. Bagaimanakah usulan perbaikan kualitas pelayanan dengan menggunakan konsep Lean Service

\section{TUJUAN PENELITIAN}

Tujuan dari Analisis Kepuasan Pelayanan Pasien pada Instalasi Rawat Jalan di Rumah Sakit Rumah SakitUmum Daerah Embung Fatimah Batam ini adalah :

1. Mengetahui tingkat kualitas pelayanan pada instalasi rawat jalan Rumah Sakit Umum Daerah Embung Fatimah Batam berdasarkan kepuasan pasien menggunakan service performance

1. Mengetahui indikator pelayanan yang berpengaruh terhadap ketidakpuasan kualitas pelayanan pada instalasi rawat jalan pada Rumah Sakit Umum Daerah Embung Fatimah Batam

2. Memberikan usulan perbaikan kualitas pelayanan dengan menggunakan konsep Lean Service 


\section{MANFAAT PENELITIAN}

Manfaat yang diharapkan dari Analisis Kepuasan Pelayanan Pasien pada Instalasi Rawat Jalan di Rumah Sakit Rumah Sakit Umum Daerah Embung Fatimah Batam ini adalah Memberikan informasi dan masukan mengenai kualitas pelayanan kepada pihak manajemen RSUD EF, serta menjadi salah satu bahan pertimbangan dalam melakukan perubahan dan perbaikan guna memberikan pelayanan yang memuaskan bagi pengunjung rumah sakit terutama pasien.

\section{KAJIAN TEORI}

\section{Service Performance}

Menurut Cronin dan Taylor (1994) dalam Setyaningsih (2013), service performance adalah kinerja dari pelayanan yang diterima oleh konsumen itu sendiri dan menilai kualitas dari pelayanan yang benar-benar mereka rasakan. ServPerf memiliki keunggulan dalam memberikan informasi atribut kualitas dan kepentingan manakah yang lebih penting untuk diperbaiki sehingga anatara keinginan dan kepentingan dapat menjadi lebih tampak dalam analisa atribut kualitas layanan Remba. Et. al, (2008) dalam Setyaningsih (2013). Hal ini diperkuat dengan pernyataan Alford dan Sherrell (1996) dalam Setyaningsih (2013), bahwa service performance akan menjadi prediktor yang baik bagi kualitas jasa atau pelayanan.

\section{Kepuasan Pelanggan}

Merupakan upaya pemenuhan sesuatu atau membuat sesuatu (memadai). Menurut Fornell (2005) dalam Tjiptono (2014) kepuasan pelanggan merupakan evaluasi purnabeli keseluruhan yang membandingkan persepsi terhadap kenerja produk dengan ekspektasi prapembelian. Kepuasan pelanggan memiliki beberapa manfaat pokok diantaranya adalah :

1. Reaksi terhadap produsen rendah

2. Manfaat ekonomik retensi pelanggan versus perspectual prospecting

3. Nilai komulatif dari relasi berkelanjutan

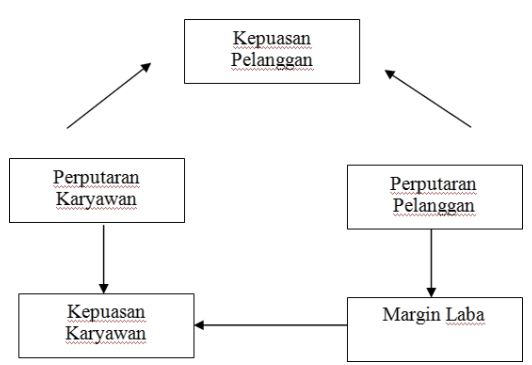

Gambar 1. Siklus Kepuasan Pelanggan (Sumber : Eka, 2015)

\section{Lean Service}

Lean service adalah sekumpulan peralatan dan metode yang dirancang untuk mengeliminasi waste, mengurangi waktu tunggu, memperbaiki performance, dan mengurangi biaya dalam Setyaningsih (2013). Lean merupakan upaya terusmenerus untuk menghilangkan pemborosan (waste) dan meningkatkan nilai tambah (value added) produk (barang dan atau jasa) agar memberikan nilai kepada pelanggan (customer value). Terdapat lima prinsip dasar lean service yaitu :

a. Spesifikasi secara tepat nilai produk yang diinginkan oleh pelanggan.

b. Identifikasi transformasi (Value Stream) untuk setiap proses jasa.

c. Eliminasi semua pemborosan yang terdapat dalam aliran proses jasa (Moment of Truth) agar nilai mengalir tanpa hambatan.

d. Menetapkan sistem anti kesalahan setiap proses jasa untuk menghindari pemborosan dan penundaan.

e. Mengejar keunggulan untuk mencapai kesempurnaan (Zero Waste) melalui peningkatan terusmenerus secara radikal.

f. Pendekatan Lean dalam layanan kesehatan, khususnya di rumah sakit, memiliki dampak signifikan bagi kualitas, biaya dan waktu dan kepuasan bagi karyawan maupun konsumen.

Hasil penelitian pada dimensi tangible seperti pengurangan waktu proses atau waktu tunggu, meningkatkan kualitas 
dengan pengurangan eror serta pengurangan biaya, dan juga faktor intangible seperti meningkatnya motivasi dan kepuasan pekerja dan meningkatkan kepuasan konsumen. Pada layanan kesehatan, lean fokus pada penilaian yang berkelanjutan untuk mengidentifikasi dan mengeliminasi waste dari pasien, kemampuan karyawan untuk menguji lingkungan kerja mereka, dan meningkatkan kualitas, keselamatan dan efisiensi dalam proses. Lean menyarankan dalam mindset karyawan medis dan administratif untuk menciptakan kapasitas pelayanan yang lebih baik dan menetapkan aturan baru, metode yang efektif dan efisien untuk pemberian pelayanan dalam Setyaningsih (2013).

\section{Importance-Performance Analysis}

Analisis ini diperkenalkan oleh Martilla \& James dalam Setyaningsih (2013) yang digunakan dalam pemasaran untuk mengidentifikasi target audiens dan laju produk tertentu atau atribut pelayanan, berdasar pada tingkat kepentingan dan dampaknya bagi performance perusahaan secara keseluruhan. Dengan menggunakan matrix ini, managemen dapat memiliki gambaran ke dalam terhadap atributatribut yang dikehendaki dan memberikan perbaikan, dan dapat dibandingkan dengan atribut-atribut yang boros dalam penggunaan sumber daya dan memberi keuntungan Pada teknik ini, responden diminta untuk menilai tingkat kepentingan dan kinerja perusahaan, kemudian nilai rata-rata tingkat kepentingan dan kinerja tersebut dianalisis pada ImportancePerformance Matrix, yang mana sumbu $\mathrm{x}$ mewakili persepsi sedangkan sumbu $\mathrm{y}$ mewakili harapan. Maka nanti akan didapat hasil berupa empat kuadran sesuai Gambar 2 berikut:

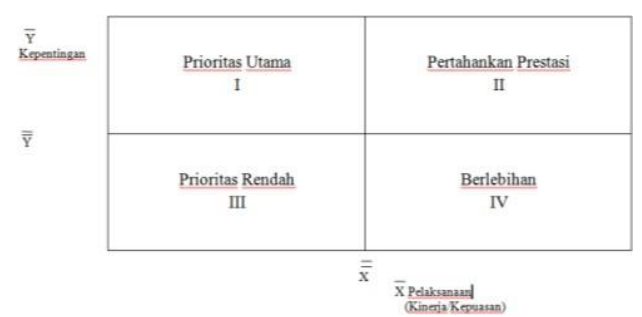

Gambar 2 Kuadran IPA

(Sumber : Setyaningsih, 2013)

Adapun pengertian empat kuadran diatas adalah :

I. Prioritas Utama

Pada kuadaran ini terdapat faktorfaktor yang dianggap penting dan atau diharapkan konsumen akan tetapi kinerja perusahaan dinilai belum memuaskan sehingga pihak perusahaan perlu berkonsentrasi untuk mengalokasikan sumber dayanya guna meningkatkan performa yang masuk pada kuadran ini.

II. Pertahankan Prestasi

Pada kuadaran ini terdapat faktorfaktor yang dianggap penting dan diharapkan sebagai faktor penunjang kepuasan konsumen sudah sesuai sesuai dengan yang dirasakan sehingga perusahaan wajib untuk mempertahankan prestasi kinerja tersebut.

III. Prioritas Rendah

Pada kuadaran ini terdapat faktorfaktor yang dianggap mempunyai tingkat persepsi atau kinerja aktual yang rendah dan tidak terlalu penting dan atau tidak terlalu diharapkan oleh konsumen sehingga perusahaan tidak perlu memprioritaskan atau memberikan perhatian lebih pada faktor-faktor tersebut.

IV. Berlebihan

Pada kuadaran ini terdapat faktorfaktor yang dianggap tidak terlalu penting dan tidak terlalu diharapkan oleh pelanggan sehingga perusahaan lebih baik mengalokasikan sumber daya yang terkait pada faktor tersebut 
Adhitomo W \& Venia, Analisis Kepuasan Pelayanan Pasien pada Instalasi...

kepada faktor lain yang lebih memiliki tingkat prioritas lebih tinggi

\section{Kerangka Penelitian}

Kerangka pemikiran dibuat guna mempermudah pemahaman mengenai penelitian yang akan dilakukan. Adapun kerangka penelitian pada penelitian ini dijelaskan pada Gambar 3.

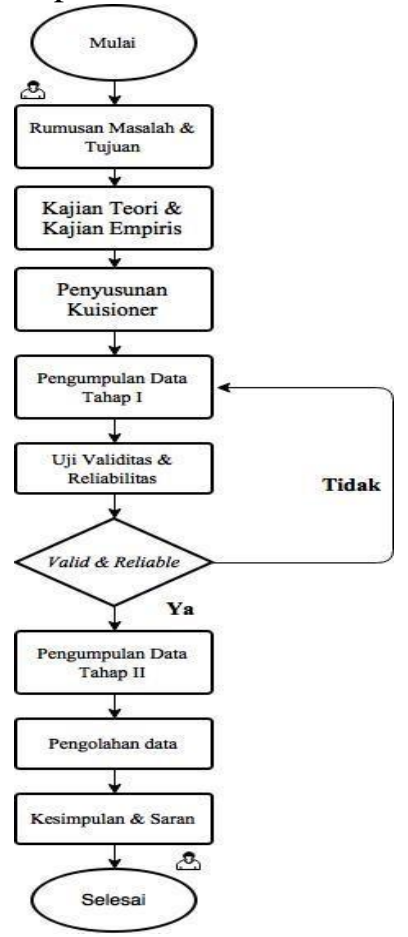

Gambar 3 Kerangka Penelitian

\section{METODE PENELITIAN}

\section{Desain/Jenis Penelitian}

Penelitian ini merupakan penelitian deskriptif yaitu penelitian yang dilakukan untuk mengetahui nilai variabel mandiri baik satu variabel atau lebih variabel tanpa membuat perbandingan atau menghubungkan anara variabel satu dengan variabel lain dan dinyatakan dalam bentuk angka

\section{Objek dan Ruang Lingkup Penelitian}

Ruang lingkup dalam penelitian ini adalah kinerja pelayanan rawat jalan yang diberikan oleh pegawai non medik Rumah Sakit Umum Daerah Embung Fatimah
Kota Batam dengan objek penelitian pasien RSUD.

\section{Operasionalisasi Variabel}

Definisi operasionalisasi variabel berisi indikator-indikator suatu variabel, yang memungkinkan peneliti mengumpul data yang relevan untuk variabel tersebut. Penelitian ini menggunakan atribut service performance yaitu variabel bukti fisik, kehandalan, daya tanggap, jaminan, empati terhadap kepuasan pelayanan. Definisi operasional masing-masing variabel dan indikatornya sebagai berikut: Bukti Fisik X1 dengan mengidentifikasi bukti fisik pelayanan rawat jalan RSUD EF Batam maka indikator yang diukur adalah: tampilan gedung yang menarik, kebersihan, keindahan dan kerapian petugas pelayanan, ketersediaan fasilitas pada ruang tunggu, ketersediaan fasilitas penunjang seperti toilet dan ruang menyusui, keadaan lingkungan ruang tunggu dan penerangan, ketersediaan saranan informasi yang mudah dijangkau

Kehandalan X2 mengidentifikasi kemampuan petugas memberikan pelayanan dengan segera, akurat, dan memuaskan maka indikator yang diukur adalah : prosedur pelayanan tidak membingungkan pasien, kehandalan dalam penyampaian informasi, informasi yang diberikan petugas dapat diandalkan, pemerosesan data dilakukan dengancepat, kehandalan dalam menggunakan teknologi.

Daya tanggap X3 mengidentifikasi daya tanggap para petugas untuk melayani keinginan calon pasien yang mendaftar dengan tanggap maka indikator yag diukur adalah : prosedur pelayanan tidak membingungkan pasien, kehandalan dalam penyampaian informasi, informasi yang diberikan petugas dapat diandalkan, pemerosesan data dilakukan dengan cepat, kehandalan dalam menggunakan teknologi

Jaminan X2 mengidentifikasi pengetahuan, kemampuan, kesopanan, 
dan sifat dapa dipercaya yang dimiliki oleh petugas maka indikator yang diukur adalah; jaminan keselamatan saat proses pelayanan, petugas pelayanan dapat menjaga kerahasiaan data calon pasien, jaminan petugas pelayanan memiliki keahlian dan keterampilan dalam melayani, pelayanan yang adil yang diberikan petugas

Empati X3 mengidentifikasi kesediaan memberikan perhatian yang mendalam dan khusu kepada pelanggan maka indikator yang diukur adalah : keramahan petugas dalam memberika pelayanan, ketulusan petugas pelayanan dalam memberikan layanan, kesediaan petugas dalam membantu pasien yang meminta bantuan, kesediaan petugas memberikan informasi yang dibutuhkan pasien

Kepuasan pelayanan $\mathrm{Y}$ kepuasan pealanggan merupakan upaya pemenuhan sesuatu atau membuat sesuatu (memadai) maka indikator yang diukur adalah: pasien puas dengan keputusan berobat, pelayanan yang diterima pasien lebih dari yang diharapkan, tujuan pasien berobat ke RSUD EF tercapai dengan baik, pasien berminat untuk kembali berobat ke RSUD EF, pasien merekomendasikan kepada orang lain untuk berobat ke RSUD EF.

\section{Populasi dan Sampel \\ Populasi}

Populasi dalam penelitian ini adalah seluruh pasien rawat jalan yang datang untuk berobat pada RSUD EF. Jumlah populasi pada penelitian ini dihitung berpatokan pada jumlah pasien rawat jalan di RSUD EF Batam pada tahun 2016 yaitu berjumlah 87.500 pasien (Sumber : Data RSUD, 2016).

\section{Sampel}

Sampel adalah sebagian dari populasi tersebut. Penelitian menggunakan teknik simple random sampling yang dilakukan secara acak tanpa ada strata, dengan jumlah sampel yang dihitung menggunakan rumus dengan rumus Slovin sebagai sebagai berikut :

Dengan :

$$
n=\frac{N}{1+N e^{2}}
$$

$\mathrm{N}=$ Jumlah Populasi

e $\quad=$ Batas Kesalahan yang ditoleransi $10 \%$

$\mathrm{n} \quad=$ Jumlah Sampel

Melalui rumus diatas dapat dihitung jumlah sampel sebagai berikut :

$$
\begin{array}{r}
n=\frac{87500}{1+87500(0.1)^{2}} \\
=99,88 \approx 100
\end{array}
$$

Berdasarkan perhitungan diatas, jumlah responden penelitian ini dengan tingkat kesalahan sebesar 10\% dan tingkat kepercayaan $90 \%$ adalah 100 responden

\section{Jenis dan Sumber Data}

Adapun jenis data dan sumber data yang digunakan dalam penelitian ini berupa :

1. Data primer, merupakan data yang diperoleh peneliti secara langsung dari sumber asli (tidak melalui perantara) melalui penyebaran kuisioner yang bersumber dari pengunjung yang akan berobat jalan di RSUD EF.

2. Data sekunder, merupakan data yang diperoleh dari perusahaan berupa profil rumah sakit, struktur organisasi, alur proses layanan serta data lain yang relevan yang dapat mendukung penelitian

\section{Teknik Pengumpulan Data}

Adapun teknik pengumpulan data yang dilakukan dalam penelitian ini adalah :

1. Kuisioner, merupakan teknik pengumpulan data yang dilakukan dengan cara memberi seperangkat pertanyaan atau pernyataan tertulis kepada responden untuk dijawabnya Sugiyono (2016). Dalam penelitian ini kuisioner dibuat sesuai dengan lima dimensi dari service quality tentang kualitas pelayanan. 
Adhitomo W \& Venia, Analisis Kepuasan Pelayanan Pasien pada Instalasi...

2. Dokumentasi, merupakan catatan peristiwa yang sudah berlalu Sugiyono, (2016). Dalam penelitian ini dokumentasi yang diambil berupa gambar yang menjelaskan proses pelayanan non medis pada instalasi rawat jalan di RSUD EF.

3. Observasi merupakan proses penelitian dengan mengamati objek yang digunakan sebagai sumber data penelitian. Dalam penelitian ini dilakukan pengamatan terhadap proses pelayanan non medis pada instalasi rawat jalan di RSUD EF.

\section{HASIL DAN PEMBAHASAN Validitas dan Reliabilitas \\ Uji Validitas}

Uji validitas dilakukan untuk memastikan seberapa baik suatu instrumen digunakan untuk mengukur konsep yang seharusnya diukur. Uji validitas dihitung dengan membandingkan nilai $r$ hitung (correlation item - total correlation) dengan nilai $r$ tabel. Jika $r$ hitung $>r$ tabel dan nilai positif maka butir atau pertanyaan tersebut dinyatakan valid. Data yang terkumpul diuji keabsahannya dengan uji validitas menggunakan korelasi product moment dengan rumus Sugiyono (2016) yaitu :

$$
r_{x \bar{y}} \frac{N \sum X Y-\left(\sum X\right)\left(\sum Y\right)}{\left(N \sum X^{2}-\left(\sum X\right)^{2}-N \sum Y^{2}-\left(\sum Y\right)^{2}\right)}
$$

Dimana :

$\mathrm{N}=$ Jumlah responden

$\mathrm{r}_{\mathrm{xy}} \quad=$ Koefisien korelasi antara $\mathrm{Y}$ dan

$\mathrm{X} \quad$ = Skor variabel independen $\mathrm{X}$

$\mathrm{Y} \quad=$ Skor variabel independen $\mathrm{Y}$

Koefisien validitas dianggap valid jika $r$ hitung > r tabel, pada alfa 5\%, yaitu :

a. Nilai pengujian Koefisien Validitas $\geq$ parameter $(0,3)$, maka pertanyaan valid.

b. Nilai pengujian Koefisien Validitas < parameter $(0,3)$, maka pertanyaan tidak valid
Hasil pengujian validitas semua item pada setiap instrumen penelitian dangan taraf signifikasi $\alpha=5 \%$, jumlah responden sebanyak 100 responden, dan $\mathrm{r}$ tabel $=0,195$ adalah sebagai berikut.

Tabel 1 Rekapitulasi hasil uji validitas instrumen penelitian Kinerja dan Kepentingan

\begin{tabular}{|c|c|c|c|c|c|}
\hline \multirow[b]{2}{*}{ Variabel } & \multicolumn{5}{|c|}{ Validitas } \\
\hline & Item & $\begin{array}{c}\text { Nilai } \\
\text { Korelasi }\end{array}$ & $\begin{array}{c}P \text {-Value } \\
\text { Kepentingan }\end{array}$ & $\begin{array}{c}P- \\
\text { Value } \\
\text { Kinerja }\end{array}$ & $\begin{array}{l}\text { Keter } \\
\text { angan }\end{array}$ \\
\hline \multirow{6}{*}{ Bukti Fisik } & $\mathrm{X} 1.1$ & 0,195 & 0,639 & 0,69 & Valid \\
\hline & $\mathrm{X} 1.2$ & 0,195 & 0,812 & 0,535 & Valid \\
\hline & $\mathrm{X} 1.3$ & 0,195 & 0,654 & 0,773 & Valid \\
\hline & X1.4 & 0,195 & 0,734 & 0,789 & Valid \\
\hline & $\mathrm{X} 1.5$ & 0,195 & 0,729 & 0,707 & Valid \\
\hline & X1.6 & 0,195 & 0,655 & 0,692 & Valid \\
\hline \multirow{5}{*}{ Kehandalan } & $\mathrm{X} 2.1$ & 0,195 & 0,586 & 0,628 & Valid \\
\hline & $\mathrm{X} 2.2$ & 0,195 & 0,755 & 0,766 & Valid \\
\hline & $\mathrm{X} 2.3$ & 0,195 & 0,748 & 0,768 & Valid \\
\hline & $\mathrm{X} 2.4$ & 0,195 & 0,775 & 0,68 & Valid \\
\hline & $\mathrm{X} 2.5$ & 0,195 & 0,624 & 0,875 & Valid \\
\hline \multirow{5}{*}{$\begin{array}{c}\text { Daya } \\
\text { Tanggap }\end{array}$} & X3.1 & 0,195 & 0,931 & 0,87 & Valid \\
\hline & $\mathrm{X} 3.2$ & 0,195 & 0,91 & 0,857 & Valid \\
\hline & X 3.3 & 0,195 & 0,877 & 0,857 & Valid \\
\hline & X3.4 & 0,195 & 0,817 & 0,602 & Valid \\
\hline & $\mathrm{X} 3.5$ & 0,195 & 0,965 & 0,872 & Valid \\
\hline \multirow{4}{*}{ Jaminan } & $\mathrm{X} 4.1$ & 0,195 & 0,924 & 0,935 & Valid \\
\hline & $\mathrm{X} 4.2$ & 0,195 & 0,894 & 0,9 & Valid \\
\hline & $\mathrm{X} 4.3$ & 0,195 & 0,8 & 0,926 & Valid \\
\hline & $\mathrm{X} 4.4$ & 0,195 & 0,967 & 0,717 & Valid \\
\hline \multirow{4}{*}{ Empati } & X5.1 & 0,195 & 0,781 & 0,625 & Valid \\
\hline & X5.2 & 0,195 & 0,891 & 0,792 & Valid \\
\hline & $\mathrm{X} 5.3$ & 0,195 & 0,826 & 0,844 & Valid \\
\hline & X5.4 & 0,195 & 0,786 & 0,673 & Valid \\
\hline
\end{tabular}

(Sumber : Pengolahan Data, 2017)

Berdasarkan pengolahan data pengujian validitas pada Tabel 1 intrumen kinerja dan kepentingan hasil pengujian menunjukan bahwa signifikasi hasil koefisien korelasi seluruh item lebih besar yaitu $r>0,195$. Sehingga dapat 
disimpulkan bahwa seluruh item yang diuji dalam penelitian adalah valid.

\section{Uji Reliabilitas}

Suatu kuesioner dikatakan reliabel atau andal jika jawaban seseorang terhadap suatu pertanyaan adalah konsisten atau stabil dari waktu ke waktu. Pengujian reliabilitas instrumen dengan menggunakan teknik Alpha Cronbach. Reliabilitas instrumen dianggap andal jika memiliki koefisien reliabilitas alpha lebih besar dari 0,60. Teknik ini cocok untuk menguji skala instrumen yang masingmasing butirnya mempunyai lebih dari satu alternatif jawaban. Suatu instrumen yang reliabel jika memiliki koefisien Alpha Cronbach di atas 0,60. Untuk menghitung reabilitas menggunakan rumus alpha, sebagai berikut:

$$
r_{11}=\frac{k}{k-1} \times\left\{1-\frac{\sum s_{i}}{s_{t}}\right\}
$$

Dimana :

$\mathrm{r}_{11} \quad=$ Nilai reliabilitas

$\sum \mathrm{S}_{\mathrm{i}} \quad=$ Jumlah varians tiap item

$\mathrm{S}_{\mathrm{t}} \quad=$ Varians total

$\mathrm{k} \quad=$ Jumlah item

Berdasarkan koefisien reliabilitas yang dipilih adalah $\alpha \geq 0,6$ karena memiliki kriteria yang dianggap cukup. Sehingga keputusan uji tes ini adalah sebagai berikut :
a. Bila nilai Alpha Cronbach $\geq$ konsta
0,6 , maka pernyataan reliabel
b. Bila nilai Alpha Cronbach < konsta
0,6 , maka pernyataan tidak reliabel
Hasil pengujian reliabilitas instrument penelitian yang berjumlah 6 dan 2 instrumen pelayanan variabel dengan rentang interprestasi cukup $0,7>\alpha \geq 0,6$ adalah sebagai berikut.

\begin{tabular}{|c|c|c|c|}
\hline Variabel & $\begin{array}{c}\text { Alpha } \\
\text { Cronbach } \\
\text { Kepenting } \\
\text { an }\end{array}$ & $\begin{array}{c}\text { Alpha } \\
\text { Cronba } \\
\text { ch } \\
\text { Kinerja }\end{array}$ & $\begin{array}{c}\text { Keterang } \\
\text { an }\end{array}$ \\
\hline $\begin{array}{c}\text { Bukti } \\
\text { Fisik }\end{array}$ & 0,796 & 0,774 & Reliabel \\
\hline $\begin{array}{c}\text { Kehandal } \\
\text { an }\end{array}$ & 0,736 & 0,797 & Reliabel \\
\hline $\begin{array}{c}\text { Daya } \\
\text { Tanggap }\end{array}$ & 0,941 & 0,865 & Reliabel \\
\hline Jaminan & 0,918 & 0,896 & Reliabel \\
\hline Empati & 0,836 & 0,707 & Reliabel \\
\hline (Sumber : Pengolahan Data, 2017)
\end{tabular}

Berdasarkan data pengujian reliabilitas pada Tabel 2 diatas, intrumen kinerja dan kepentingan hasil pengujian menunjukan bahwa nilai Alpha Cronbach yang dihasilkan oleh setiap item pernyataan menunjukan angka $>0,6$. Sehingga dapat disimpulkan bahwa keenam variabel penelitian tersebut dapat dinyatakan reliabel.

\section{Metode Analisis Data \\ Importance-Performance Analysis}

Analisis ini dilakukan untuk mengetahui tingkat kepuasan pelayanan yang dirasakan oleh pasien terhadap kinerja yang diberikan oleh petugas pelayanan non medis pada instalasi rawat jalan di Rumah Sakit Umum Daerah Embung Fatimah Batam yang dituangkan didalam kuadran yang memiliki 4 tipe kuadran yang berbeda. Sebelum memetakan kedalam kuadran terlebih dahulu menhitung tingkat kesesuaian ratarata antara kinerja dan kepentingan seperti pada Tabel 3 dibawah ini. 
Adhitomo W \& Venia, Analisis Kepuasan Pelayanan Pasien pada Instalasi...

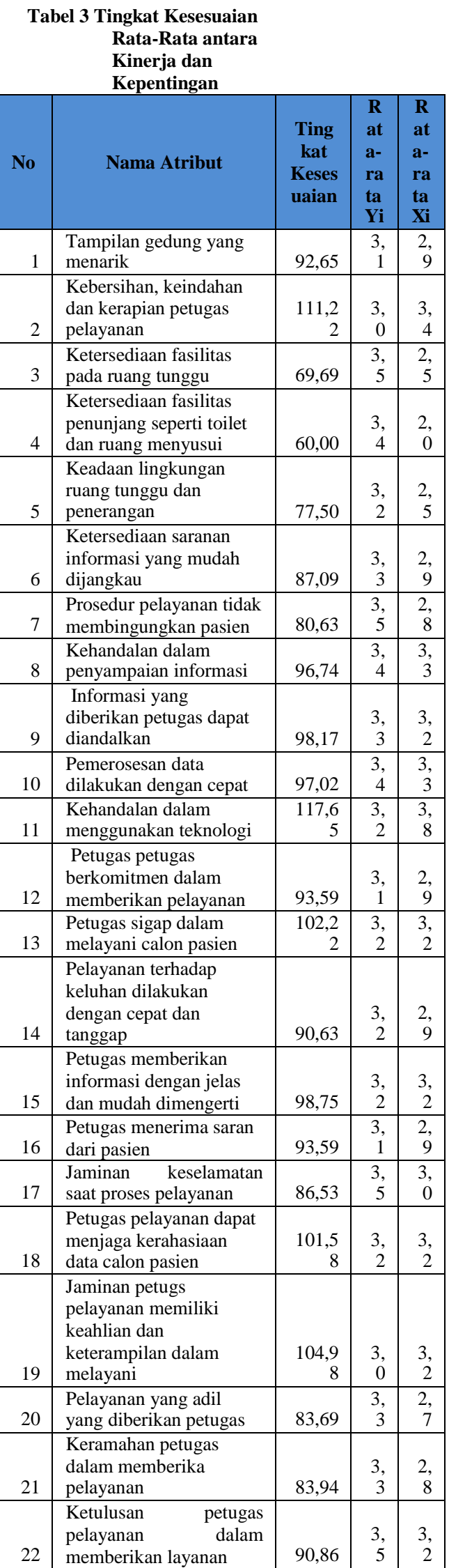

\begin{tabular}{|c|c|c|c|c|}
\hline No & Nama Atribut & $\begin{array}{l}\text { Ting } \\
\text { kat } \\
\text { Keses } \\
\text { uaian }\end{array}$ & $\begin{array}{l}\text { R } \\
\text { at } \\
\text { a- } \\
\text { ra } \\
\text { ta } \\
\text { Yi }\end{array}$ & $\begin{array}{l}\text { R } \\
\text { at } \\
\text { a- } \\
\text { ra } \\
\text { ta } \\
\text { Xi }\end{array}$ \\
\hline 23 & $\begin{array}{l}\text { Kesediaan petugas dalam } \\
\text { membantu pasien yang } \\
\text { meminta bantuan }\end{array}$ & 84,17 & $\begin{array}{r}3 \\
6\end{array}$ & $\begin{array}{r}3, \\
0\end{array}$ \\
\hline 24 & $\begin{array}{l}\text { Kesediaan petugas } \\
\text { memberikan informasi } \\
\text { yang dibutuhkan pasien }\end{array}$ & 94,55 & $\begin{array}{r}3 \\
3\end{array}$ & $\begin{array}{r}3, \\
1 \\
\end{array}$ \\
\hline & Rata-Rata & 91,56 & $\begin{array}{c}3 \\
3\end{array}$ & $\begin{array}{r}3, \\
0\end{array}$ \\
\hline
\end{tabular}

(Sumber : Data Olahan Peneliti, 2017)

Tabel 3 diatas menjelaskan hubungan kesesuaian antara tingkat kepentingan dan tingkat kinerja, jika persentase $<80 \%$ maka dikatakan bahwa kinerja dari masing-masing atribut tidak dapat memenuhi harapan dari responden, jika persentase $80-100 \%$ maka dikatakan kinerja dari masing-msing indikator telah dapat memenuhi harapan dari konsumen tetapi masih perlu diperbaiki lagi, dan jika persentase $>100 \%$ dapat dikatakan kinerja indikator tersebut telah melebihi dengan harapan konsumen Indrawingsih dan Sudrayanto (2007).

Pada Tabel 4.12 tingkat kesesuaian rata-rata sebesar $91,56 \%$ dengan rentang nilai pada kisaran $60,0 \%$ s/d 117,65\%. Atribut yang memiliki nilai sebesar $60,0 \%$ merupakan atribut dari bentuk fisik dengan indikator fasilitas penunjang, ruang tunggu dan toilet dirasa masih belum sesuai dengan apa yang diharapkan pasien sehingga pihak RSUD perlu melakukan perbaika. Indikator yang memiliki nilai $117,65 \%$ adalah kehandalan petugas dalam menggunakan teknologi ini menandakan kemampuan petugas dalam menggunakan teknologi seperti komputerisasi telah sangat sesuai dengan harapan sehingga pihak RSUD perlu mempertahankan kualitasnya.

Nilai rata-rata tingkat kepentingan sebesar 3,3 dan rata-rata tingkat kinerja sebesar 3,0. Nilai rata-rata tersebut akan digunakan dalam menentukan diagram kartesius. Berikut penjabaran kuadran importance performance analysis : 


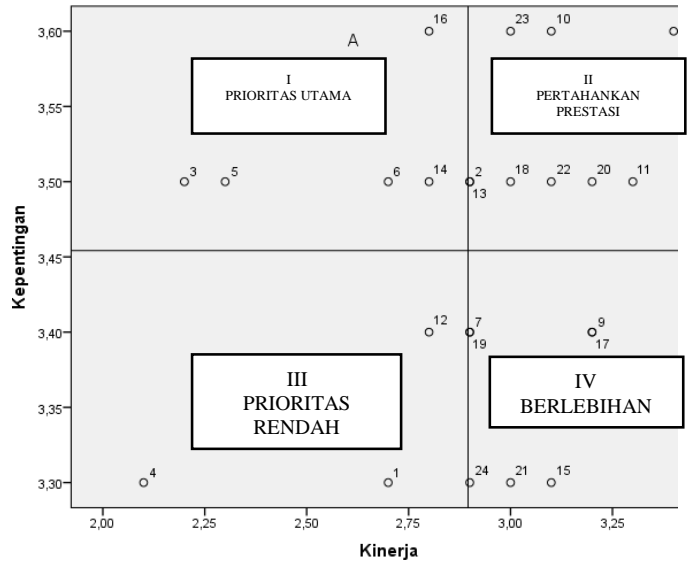

Gambar 4 Penjabaran indikator dalam Diagram Kartesius

(Sumber : Pengolahan Data, 2017)

Berdasarkan gambar 4 penjabaran atribut dalam diagram kartesius diatas meggambarkan keadaan yang berbeda. Pemetaan berdasarkan tingkat kepentingan dan kinerja memungkinkan pihak RSUD untuk segera melakukan perbaikan pada atribut yang dianggap penting oleh pasien. Pejelasan setiap kuadran adalah sebagai berikut : Kuadaran II (Prioritas Utama)

Adapun indikator tersebut adalah :

a. Parnyataan nomor 3 yang menyatakan fasilitas ruang tunggu yang memadai seperti TV AC

b. Pernyataan nomor 5 yang menyatakan lingkungan ruang tunggu dan penerangan baik

c. Pernyataan nomor 6 yang menyatakan ketersediaan papan informasi yang mudah dijangkau

d. Pernyataan nomor 14 yang menyatakan pelayanan terhadap keluhan pasien dilakukan dengan cepat dan tanggap

e. Pernyataan nomor 16 yang menyatakan petugas menerima saran dari pasien

Kuadran II (Pertahankan Prestasi) Adapun indikator tersebut adalah :

a. Pernyataan nomor 2 yang menyatakan kebersihan, kerapian, dan keindahan petugas pelayanan

b. Pernyataan nomor 8 yang menyatakan petugas mampu menyampaikan informasi yang diinginkan

c. Pernyataan nomor 10 yang menyatakan pemprosesan data dilakukan dengan cepat dan tepat

d. Pernyataan nomor 11 yang menyatakan petugas mampu menggunakan teknologi yang tersedia

e. Pernyataan nomor 13 yang menyatakan petugas sigap dalam melayani pasien

f. Pernyataan nomor 18 yang menyatakan petugas pelayanan dapat menjaga kerahasiaan data pasien

g. Pernyataan nomor 20 yang menyatakan pasien mendapat pelayanan yang adil dan tidak memandang status

h. Pernyataan nomor 22 yang menyatakan petugas memberikan perhatian yang tulus saat melayani pasien

i. Pernyataan nomor 23 yang menyatakan petugas bersedia membatu pasien yang meminta bantuan

Kuadran III (Prioritas Rendah)

Adapun indikator tersebut adalah :

a. Pernyataan nomor 1 yang menyatakan tampilan gedung yang menarik

b. Pernyataan nomor 4 yang menyatakan lingkungan ruang tunggu dan penerangan yang baik

c. Pernyataan nomor 12 yang menyatakan petugas komitmen dalam melayani pasien

Kuadran IV (Berlebihan) Adapun indikator tersebut adalah :

a. Pernyataan nomor 7 yang menyatakan prosedur pelayanan yang mudah

b. Pernyataan nomor 9 yang menyatakan informasi yang diberikan oleh petugas RSUD dapat diandalkan 
Adhitomo W \& Venia, Analisis Kepuasan Pelayanan Pasien pada Instalasi...

c. Pernyataan nomor 15 yang menyatakan petugas memberikan informasi dengan jelas dan mudah dimengerti

d. Pernyataan nomor 17 yang menyatakan terdapat jaminan keselamatan saat proses pelayanan

e. Pernyataan nomor 19 yang menyatakan petugas pelayanan memiliki keahlian dan keterampilan dalam melayani

f. Pernyataan nomor 21 yang menyatakan keramahan petugas saat memberikan pelayanan

g. Pernyataan nomor 24 yang menyatakan kesediaan petugas memebrikan informasi yang dibutuhkan pasien

\section{Lean Service}

Hasil pemetaan kuadran dengan menggunakan metode servperf Importance Perfomance Analisis (IPA) diatas menunjukan terdapat lima atribut dalam dimensi kualitas pelayanan di RSUD Embung Fatimah Batam yang memiliki tingkat kepentingan tinggi namun masih memiliki kinerja yang rendah. Kelima indikator tersebut merupakan aspek CTQ yang perlu untuk dilakukan perbaikan adalah sebagai berikut :

Tabel 4 Aspek Critical To Quality (CTQ)

\begin{tabular}{|c|c|c|c|}
\hline No & $\begin{array}{l}\text { Dimensi } \\
\text { Kepuasan } \\
\text { Pelayanan } \\
\end{array}$ & Indikator & $\begin{array}{l}\text { Kode } \\
\text { SPSS }\end{array}$ \\
\hline \multirow{3}{*}{1} & \multirow{3}{*}{$\begin{array}{l}\text { Bukti } \\
\text { Fisik }\end{array}$} & $\begin{array}{l}\text { Fasilitas ruang tunggu } \\
\text { yang memadai }\end{array}$ & 3 \\
\hline & & $\begin{array}{l}\text { Lingkungan ruang } \\
\text { tunggu dan penerangan } \\
\text { Baik }\end{array}$ & 5 \\
\hline & & $\begin{array}{l}\text { Ketersediaan papan } \\
\text { nformasi yang mudah } \\
\text { dijangkau }\end{array}$ & 6 \\
\hline \multirow[t]{2}{*}{2} & \multirow[t]{2}{*}{$\begin{array}{c}\text { Daya } \\
\text { Tanggap }\end{array}$} & $\begin{array}{lr}\text { Pelayanan } & \text { terhadap } \\
\text { keluhan } & \text { pasien } \\
\text { dilakukan dengan cepat } \\
\text { dan tanggap }\end{array}$ & 14 \\
\hline & & $\begin{array}{l}\text { Petugas menerima saran } \\
\text { dari pasien }\end{array}$ & 16 \\
\hline
\end{tabular}

(Sumber : Pengolahan Data, 2017)

Berdasarkan hasil identifikasi CTQ pada tabel 4 diatas maka, langkah selanjutnya dilakukan pendefinisian proses yang akan diperbaiki dengan memetakan proses pelayanan RSUD untuk memberikan gambaran umum mengenai aliran fisik serta aliran informasi dari proses layanan yang diamati. Kemudian menetukan rencana atau rekomendasi tindakan dan menetukan prioritas rencana tindakan.

\section{Pembahasan}

Berdasakan hasil anaisis data yang telah penulis lakukan secara umum kepuasan pelayanan yang diberikan oleh RSUD Embung Fatimah telah menunjukan hasil yang baik hal ini dapat dilihat dari tingkat kesesuaian yang ditunjukan oleh variabel Y yakni kepuasan pelayanan. Pada atribut kepentingan nilai rata-rata variabel $\mathrm{Y}$ menunjukan angka 3,22 sedangkan ada atribut kinerja nilai rata-rata variabel $\mathrm{Y}$ menunjukan angka 3,04 dari angka tersebut didapapatkan nilai tingkat keseuaian sebesar 94,53. Hal ini berarti kepuasan pelayanan yang dirasakan oleh paien terhadap kinerja RSUD telah dapat memenuhi harapan dari pasien itu sendiri namun masih perlu diperbaiki.

Hasil pemetaan kuadran metode servperf pada analisis important performance analysis menunjukan adanya lima indikator dalam dimensi kualitas pelayanan yang memiliki tingkat kepentingan tinggi namun masih memiliki kinerja yang rendah yaitu :

1. Fasilitas ruang tunggu yang memadai seperti TV AC

2. Lingkungan ruang tunggu dan penerangan baik

3. Ketersediaan papan informasi yang mudah dijangkau

4. Pelayanan terhadap keluhan pasien dilakukan dengan cepat dan tanggap

5. Petugas menerima saran dari pasien Kelima indikator tersebut merupakan aspek Critical To Quality (CTQ) yang perlu dilakukan perbaikan. Berdasarkan aspek Critical To Quality (CTQ) tersebut maka langkah selanjutnya adalah mendefinisikan pemilihan proses yang akan diperbaiki dengan memetakan proses 
bisnis untuk memberikan gambaran umum tentang aliran fisik dan aliran informasi dari proses layanan yang diamati sebagai berikut :

1. Fasilitas ruang tunggu yang memadai seperti TV AC dari atribut bukti fisik memiliki kinerja rendah karena :

a. Desain ruang tunggu dengan berlorong-lorong sehingga tidak mudah menyesuaikan peletakan fasilitas pendukung yang benarbenar sesuai

b. Ketersediaan kursi jumlah kursi yg kurang dapat menampung pasien

2. Lingkungan ruang tunggu dan penerangan baik dari atribut bukti fisik memiliki kinerja rendah karena :

a. Banyaknya pengunujung rumah sakit setiap harinya dengan tidak didukung dengan luas ruangan menjadikan lingkungan ruang tunggu yang pengap dan kurang nyaman

3. Ketersediaan papan informasi yang mudah dijangkau dari atribut daya tanggap memiliki kinerja rendah karena :

a. Keadaan ruangan yang baru selesai direnovasi sehingga belum banyak papan informasi yang tersedia

b. Terdapat petugas customer service yang melayani informasi

4. Pelayanan terhadap keluhan pasien dilakukan dengan cepat dan tanggap dari indikator daya tanggap memiliki kinerja rendah karena :

a. Petugas yang terlalu berorientasi pade job desk

b. Banyaknya pasien, kurang seimbang dengan tenaga pelayanan yang ada

5. Petugas menerima saran dari pasien dari atribut daya tanggap memiliki kinerja rendah karena

a. Beban kerja yang besar dalam tugas, sehingga karyawan terkadang kurang tanggap terhadap keluhan pasien

Setelah dilakukan pemilihan proses yang akan diperbaiki dengan memetakan proses bisnis untuk memberikan gambaran umum tentang aliran fisik dan aliran informasi dari proses layanan yang diamati, kemudian dilakukan identifikasi NVA (Non Value Added) dan VA (Value Added) sebagai berikut :

1. Fasilitas ruang tunggu yang memadai serta lingkungan ruang tunggu dan penerangan baik

a. NVA : Fungsi falitas-fasilitas yang ada pada ruang tunggu yang ada belum termaksimalkan dikarenakan tata letaknya yang kurang strategis

b. VA : Merancang ulang tata letak fasilitas ruang tunggu

2. Ketersediaan papan informasi yang mudah dijangkau

a. NVA : Informasi yang tersedia hanya berupa informasi mengenai seputar kesehatan dan visi misi rumah sakit.

b. VA : Memberikan papan informasi mengenai jadwal dokter dan pengumuman seputar kegiatan yang berhubungan dengan rawat jalan

3. Pelayanan terhadap keluhan pasien dilakukan dengan cepat dan tanggap serta petugas menerima saran dari pasien

a. NVA : Dalam memberikan pelayanan terhadap pasien, petugas pelayanan kurang tanggap mengingat banyaknya pekerjaan yang harus diselesasikan sehingga petugas lebih berorientasi pada tugas

b. VA : Menambah jumlah petugas pelayanan non medis

Dari NVA (Non Value Added) dan VA (Value Added) yang ada maka penulis merekomendasikan tindakan (recommendation plan) serta menetukan prioritas tindakan (action plan priority) diharapkan dapat memaksimalkn nilai kepentingan yang diharapkan oleh pasien rawat jalan RSUD Embung Fatimah Batam. 
Adhitomo W \& Venia, Analisis Kepuasan Pelayanan Pasien pada Instalasi...

1. Fasilitas ruang tunggu yang memadai serta lingkungan ruang tunggu dan penerangan baik

a. Merancang ulang tata letak ruang tunggu yang ada pada instalasi rawat jalan RSUD

b. Memperbanyak jumlah kursi terutama pada ruang tunggu di tiap poliklinik

c. Memberikan sofa atau kursi busa yang lebih banyak dari jumlah yang ada

d. Menyesuaikan sistem pendingin ruangan dengan jumlah pasien yang berkunjung

2. Ketersediaan papan informasi yang mudah dijangkau
a. Menyediakan tempat khusus informasi mengenai jadwal dokter serta seputar pelayanan rawat jalan
b. Memberikan pemahaman mendalam kepada petugas informasi mengenai tugas dan fungsinya

3. Pelayanan terhadap keluhan pasien dilakukan dengan cepat dan tanggap serta petugas menerima saran dari pasien

a. Memberikan pelatihan dan pemahaman kepada petugas pelayanan pelayanan kebutuhan pasien harus diperhatikan dengan baik

b. Menambah jumlah pegawai non medis sehingga mengurangi beban kerja agar dapat memaksimalkan kinerja

\section{SIMPULAN DAN SARAN \\ Simpulan}

Berdasarkan hasil penelitian yang telah dilakukan mengenai analisis kepuasan pelayanan instalasi rawat jalan di Rumah Sakit Umum Daerah Embung Fatimah dengan pendekatan lean service dan service performance, maka penulis menyimpulkan bahwa :

1. Tingkat kualitas pelayanan pada instalasi rawat jalan Rumah Sakit
Embung Fatimah Kota Batam berdasarkan Embung Fatimah berda sarkan kepuasan pasien menggunakan service performance menunjukan angka 94,53\% yang yang berarti pelayanan yang diberikan oleh RSUD telah dapat memenuhi harapan pasien.

2. Indikator pelayanan yang berpengaruh terhadap ketidakpuasan kualitas pelayanan pada instalasi rawat jalan pada Rumah Sakit Embung Fatimah terdapat lima indikator yang tergolong kedalam kuadadran A adalah sebagai berikut :

a. Parnyataan nomor 3 yang menyatakan fasilitas ruang tunggu yang memadai seperti TV AC

b. Pernyataan nomor 5 yang menyatakan lingkungan ruang tunggu dan penerangan baik

c. Pernyataan nomor 6 yang menyatakan ketersediaan papan informasi yang mudah dijangkau

d. Pernyataan nomor 14 yang menyatakan pelayanan terhadap keluhan pasien dilakukan dengan cepat dan tanggap

e. Pernyataan nomor 16 yang menyatakan petugas menerima saran dari pasien

3. Usulan perbaikan kualitas pelayanan dengan menggunakan konsep Lean Service adalah sebagai berikut :

1. Fasilitas ruang tunggu yang memadai serta lingkungan ruang tunggu dan penerangan baik dengan :

e. Merancang ulang tata letak ruang tunggu yang ada pada instalasi rawat jalan RSUD

f. Memperbanyak jumlah kursi terutama pada ruang tunggu di tiap poli

g. Memberikan sofa atau kursi busa yang lebih banyak dari jumlah yang ada

h. Menyesuaikan sistem pendingin ruangan dengan 
jumlah pasien yang
berkunjung

2. Ketersediaan papan informasi yang mudah dijangkau dengan :

c. Menyediakan tempat khusus informasi mengenai jadwal dokter serta seputar pelayanan rawat jalan

d. Memberikan pemahaman mendalam kepada petugas informasi mengenai tugas dan fungsinya

3. Pelayanan terhadap keluhan pasien dilakukan dengan cepat dan tanggap serta petugas menerima saran dari pasien dengan :

c. Memberikan pelatihan dan pemahaman kepada petugas pelayanan mengenai pelayanan kebutuhan pasien harus diperhatikan dengan baik

d. Menambah jumlah pegawai non medis sehingga mengurangi beban kerja agar dapat memaksimalkan kinerja

\section{Saran}

Berdasarkan penelitian yang telah penulis lakukan, adapun saran yang dapat penulis sampaikan adalah sebagai berikut

1. Bagi penelitian selanjutnya agar dapat memperluas ruang lingkup penelitian demi penyamarataan kualitas pelayanan mengingat penelitian ini hanya mengambil lingkup pelayanan non medis.

2. Kepada pihak manajemen Rumah Sakit Umum Daerah Embung Fatimah diharapkan lebih mempermudah proses perizinan untuk dilakukannya penelitian di RSUD mengingat penelitian tersebut semata-mata demi perbaikan kualitas rumah sakit itu sendiri

3. Terhadap hasil penelitian ini diharapkan pihak manajemen mempertimbangkan serta menindaklanjuti usulan perbaikan yang dihasilkan berdasarkan pendekatan lean service

\section{Keterbatasan}

Pada penelitian ini penulis tidak meneliti keseluruhan daripada rumah sakit melainkan penulis hanya meneliti petugas pelayanan pada bidang non medis. Hal ini dikarenakan keterbatasan penulis dalam melakukan penelitian mengingat objek keseluruhan rumah sakit yang sangat luas. Disamping itu penelitian ini hanya mengambil dari sudut pandang pasien saja sehingga tidak ada perbandingan tentang apa yang dirasakan oleh pasien dengan apa yang telah dilakukan oleh pegawai. Diharapkan bagi peneliti selanjutnya agar dapat menambahkan sudut pandang dari kedua belah pihak agar rekomendasi perbaikan lebih ter intgrasi dan tepat.

\section{Daftar Pustaka}

Arikunto. (2006). Prosedur Penelitian Suatu Pendekatan Praktek Edisi Revisi V. Jakarta: Rineka Cipta.

Chitami Puti, Widya, W.C. (2013). Pengaruh Kualitas Pelayanan dan Kepuasan Terhadap Loyalitas Pasien Rawat Jalan dan Rawat Inap. 5. 35-57

Danang, S \& Eka Susanti, F. (2015). Manajemen Pemasaran Jasa. Yogyakarta. CAPS (Center For Academic Publishing Service).

Dharmauanti, Dian. DN. (2006). Analisis Dampak Service Performance dan Kepuasan Sebagai Moderating Variable Terhadap Loyalitas Nasabah.1. 35-43.

Mira Asrikusuma, Triana. M.R. (2000). Analisis Kualitas Pelayanan (Service Performance) pada Rumah Sakit Pelayanan Kesehatan Umum (PKU) Muhammadiyah Karanganyar Surakarta. 1-147

Nakhai, Behnam. B.N. (2012). The challenges of six sigma in improving service quality. 39-57.

Panuti, Sri. Kirana Anggraeni, Shanti. Baharudin, Achmad. S.A (2013). 
Adhitomo W \& Venia, Analisis Kepuasan Pelayanan Pasien pada Instalasi...

Rancangan Perbaikan Kualitas Layanan Poliklinik Kulit dan Kelamin RSUD Cilegon dengan Pengintegrasian Metode Servqual, Lean dan Six Sigma. 2-(2302-495X). 169-173.

Peraturan Daerah Kota Batam Nomor 7 Tahun 2013 tentang susunan organisasi dan tata kerja Rumah Sakit Umum Daerah Embung Fatimah Kota Batam

Peraturan Menteri Kesehatan Republik Indonesia nomor 340/MENKES/PER/III/2010.

Tentang pengertian rumah sakit.

Peraturan Menteri Kesehatan Indonesia Nomor HK.02.03/1/01/0154/2013

tentang standarisasi pelayanan medik umum rumah sakit

Rahmawati, \& Herlina (2010). Analisis Kualitas Pelayanan Jasa Menggunakan Metode Servqual dan Importance Performance Analysis Di Kantor Perpustakaan dan Arsip Kabupaten Karanganyar. 57-80

Setyaningsih, Ira. (2013). Analisis Kualitas Pelayanan Rumah Sakit Terhadap Pasien Menggunakan Pendekatan Lean Servperf (Lean Service Dan Service Performance).11-(1963-6590). 133148.

Sugiyono, S. (2016). Metode Penelitian Manajemen $\left(5^{\text {th }} \quad\right.$ ed.). Bandung. ALFABETA, CV.

Sugiyono, S. (2011). Metode Penelitian Adminstrasi Dilengkapi dengan Metode $R \& D$ (19 $9^{\text {th }}$ ed.). Bandung. ALFABETA, CV.

Tjiptono, Fandy, F.T. (2014). Pemasaran Jasa Prinsip, Penerapan, dan Penelitan. CV. Andi Offset.

Asih, Widuri \& Endang. E.D. (2016). Penentuan Atribut Kepuasan Pelanggan Dengan Menggunakan Integrasi Model Kano dan Six Sigma Pada Koperasi Simpan Pinjam. (978979-3649-962). 274-283.
Wijaya, Handi. (2012). Analisi Pelaksanaan Standar Pelayanan Minimal (SPM) Rumah Sakit Bidang Farmasi di Instalasi Farmasi Rumah Sakit Tugu Ibu Tahun 2012. 1-174 